\title{
MORE ON THE CREDIT CHANNEL OF MONETARY POLICY TRANSMISSION: AN INTERNATIONAL COMPARISON*
}

\author{
Pablo de Andrés Alonso** \\ Félix J. López Iturriaga \\ Universidad de Valladolid
}

En este trabajo presentamos algunos indicios del funcionamiento del canal del crédito como una forma posible de transmisión de las medidas de política monetaria. El tema se aborda desde una perspectiva internacional, en la que se compara la reacción ante los cambios en la política monetaria de las empresas no financieras de doce países de la OCDE. Haciendo uso del tipo de interés como un indicador del estado de la política monetaria, encontramos que dicho tipo de interés afecta a las decisiones de inversión de las empresas a través de la disponibilidad de crédito bancario, especialmente en el corto plazo. Estos resultados parecen evidenciar una distinta efectividad de la política monetaria en función de las características del sistema financiero de cada país, de modo que en los países con una mayor orientación hacia el mercado, en los cuales la financiación bancaria reviste menor importancia, las decisiones empresariales no se ven tan modificadas como en los países de mayor orientación hacia la intermediación financiera.

In this paper we provide some evidence of the credit channel as a possible way of transmitting monetary policy decisions. We do it in an international framework by comparing the reaction of non-financial companies of twelve OECD countries to changes in monetary policy. Using the interest rate as an indicator of the stance of monetary policy, we find that the interest rate does affect firms' investment and output by altering their bank finance availability, specially the short-term finance. Our results also seem to show a rather different effectiveness of the monetary policy depending on the features of the financial system of each country. In those countries with a more market-oriented financial system, corporate finance relies less heavily on banks, so they are not so influenced by shifts in monetary policy as companies of other more bank-based countries .

PALABRAS CLAVE: Canal del crédito, financiación empresarial, transmisión financiera, política monetaria, vectores autorregresivos.

KEYWORDS: Corporate finance, credit channel, financial propagation, monetary policy, vector autorregression.

\section{INTRODUCTION.}

In recent years many scholars have devoted their attention to the way through which monetary policy affects the economy. ${ }^{137}$ Of course, this is not a new research topic since the appearance of the basic keynesian IS/LM textbook model. However, new explanations have been provided based on capital market imperfections instead of the traditional liquidity effect.

One of the outstanding questions is how small shocks in monetary policy may produce big effects on borrowing and spending. An exclusive macroeconomic perspective seems to be no longer useful, so we should to look for new answers, as Bernanke and Gertler (1995) suggest, inside the black box. It is for this reason that these alternative approaches focus on some features of the companies and capital markets which can propagate and even amplify any shock in the economy which it is not far from what Blinder and Maccini (1991) have called "microfoundations of macroeconomics". In this sense, some firms would face financial constraints making their investment decisions heavily dependent on their own financial situation and providing a link among business cycles, monetary policy and their own company behavior.

The aim of this paper is to provide evidence for one of the possible channels of monetary transmission: the credit channel. This is not only a way of acting on aggregate spending and output, but also it could shed some light on the small shocks/big effects paradox. The credit channel actually

\footnotetext{
* An earlier version of this paper was presented in the Conference of the European Association of University Teachers of Banking and Finance held in Amsterdam.

*** The authors thank Valentín Ruesga (Universidad de Valladolid) for his comments and patient assistance.

${ }^{137}$ Two examples of the increasing interest on the issue are the last symposia on Monetary Transmission Mechanism and Developments in Business Cycle Research. Proceeding were subsequently published in the Journal of Economic Perspectives (1995) and the Review of Economics and Statistics (1996), respectively.
} 
includes two complementary channels: the bank lending and the balance sheet channels, whose activity, although theoretically quite different, is not easy to distinguish empirically. Obviously this is not the only theory about monetary transmission mechanisms but the latest developments in imperfect information, agency costs and other frictions in credit markets (Postlewaite, 1987) seem to show some gaps in conventional theories.

At the same time, another appeal of the subject lies in the fact that the mainstream of the literature on the topic has been concentrated on the US experience, but there are almost no papers -at least, as far as we know- on an international framework comparing the situation among countries with fairly different financial systems.

From our point of view, the above reasons justify this paper in which, using several OECD countries data, we give an initial evidence supporting the credit channel of monetary policy. In section II we provide an overview of the transmission mechanisms of monetary policy. This section also shows a combination of macroeconomic and firm-level topics such as the role of corporate finance in the origin and propagation of economic cycles. In section III we expose the basic assumptions of the empirical part of the paper, the methodology applied and the data utilized. Results are shown in section IV, which is followed by a final section containing some concluding remarks.

\section{MONETARY POLICY, CREDIT CHANNEL AND CORPORATE FINANCE: AN OVERVIEW.}

There is no doubt that monetary policy has replaced fiscal policy for the late 1980s and ' 90 s as the central instrument in promoting sustainable growth and low inflation (Mishkin, 1995 and 1996). The agreement also extends the ability of monetary policy to influence the course of real economy but not how these actions exert their influence (Bernanke and Gertler, 1995). At least, three theories have been appointed in order to give a complete explanation: the traditional interest rate channel, the other assets price channel and the credit channel.

The first constitutes the basis of the IS/LM model and underlines the relationship between the interest rate and the cost of capital. In short, it can be characterized by saying that an expansionary monetary policy is followed by a fall in interest rate. Given that the usual expression of the cost of capital includes the interest rate (Jorgenson, 1963 and 1967), any variation in the latter makes the cost of capital go in the same direction. The result is an increase in consumer and business investment, causing a rise in output. However, although it has been one of the first justifications proposed and some authors proved its validity (Taylor, 1995), this mechanism is controversial and has received severe criticism.

On the one hand, it is not clear the coordination between long and short-term rates. If monetary policy is supposed to have its main effects on short-term interest rates, it remains unanswered satisfactorily how the purchases of long-lived assets -which should respond to long-term rates rather than to short-term ones- are affected by an intervention in short-term rates. On the other hand, beyond this question, many works have shown that business investment is even so responsive to financial variables as to neoclassical factors in every country (see Fazzari, Hubbard and Petersen, 1988 for USA $^{138}$; Devereux and Schiantarelli, 1990 for UK; Galeotti, Schiantarelli and Jaramillo, 1994 for Italy; Hoshi, Kashyap and Scharfstein, 1990a, b and 1991 for Japan; Alonso, 1994 for Spain; Schaller, 1993 for Canada; Broer and Leeuwen, 1994 for the Netherlands). This strong evidence is not only related to fixed investment (Chirinko, 1993), but also to inventory investment (Blinder and Maccini, 1991), labor force demand (Sharpe, 1994) or consumption (Zeldes, 1989). Therefore, new approaches to the problem were necessary all coming from the so-called other assets price channel (Meltzer, 1995).

\footnotetext{
${ }^{138}$ The literature on this issue is quite huge, so we have only quoted one of the first papers for each country. Specially for USA there is an enormous set of contributions showing the impact of liquidity and other financial variables on investment as Calomiris and Hubbard (1989, 1990 and 1995), Gertler, Hubbard and Kashyap (1991), Whited (1991 and 1992), Hubbard and Kashyap (1992), Oliner and Rudebusch (1992), Fazzari and Petersen (1993), Calomiris, Orphanides and Sharpe (1994), Vogt (1994), Hubbard, Kashyap and Whited (1995), Calem and Rizzo (1995), Gilchrist and Himmelberg (1995).
} 
The other assets price channel is not a single mechanism, but again two different ways of transmission can be distinguished: the exchange rate and the equity price channels. They share the recognition that it is not adecuate to focus just on one asset price and the convenience of considering two other price effects: the foreign exchange rate and the equity prices.

Briefly, the exchange rate channel relies on the assumption that this rate affects the domestic currency value altering the attraction of the goods produced in the country. This result may be caused by a decrease in the interest rate (an expansionary monetary policy) because the lower the interest rate the less attractive the deposits are relative to deposits in foreign countries. In turn, any reduction in the prices of the goods makes exports increase, thereby causing a rise in output.

The equity price channel stresses the competition between bonds and equities as potential investments. If monetary policy decisions reduce the interest rate, investors will choose the underwriting of shares instead of bonds, originating a rise in their prices. When stock prices rise, there is also a rise in consumer and business investment. The final consequence of such decisions is a growth of aggregate output.

Although many papers supporting the two above transmission mechanisms can be found, the most promising and emergent explanation is perhaps the credit channel. Its key point is the emphasis on asymmetric information and how this imperfection introduces frictions in capital markets ${ }^{139}$ and contains two complementary ways of transmission: bank lending and balance sheet (Gertler and Gilchrist, 1994).

The asymmetric information often characterizing capital markets is the starting point for banks as institutions specially suited to solve those problems (Chevallier-Farat, 1992). Their expertise acquired in evaluating and screening applicants enables them to extend credit to customers who cannot obtain it in open markets. When an expansionary monetary policy facilitates bank credit availability through increasing bank reserves and deposits, the aggregate reaction of the economy is a rising amount of investment and, in turn, of output. This is, roughly speaking, the bank lending channel. But, as Kashyap, Stein and Wilcox (1993) have suggested, if the lending channel works, two conditions must be satisfied: firstly, loans and any other sort of credit (commercial paper, bonds, etc.) must be imperfect substitutes as bank assets, and secondly loans and other credits have to be imperfect substitutes as corporate liabilities.

The balance sheet channel also outlines the increase of lending under an expansionary monetary policy, but indirectly. Firms usually present their net worth as a collateral so as to diminish the moral hazard and adverse selection problems associated with bank finance. If a monetary policy improves the company balance sheet, the discount rate for the cash flow is reduced, its net worth rises, the company credit ability grows and so its investment and output.

The credit channel can be per se an appropriate explanation of the transmission mechanism but its effectiveness is multiplied when introducing a characteristic of capital markets such us the credit rationing (Stiglitz and Weiss, 1981; Greenwald, Stiglitz and Weiss, 1984). Broadly, this fact is due to information problems which lead banks to deny credit to customers even when they are willing to pay a higher interest rate than that which is in effect at the moment. If this is the case, a monetary policy making easy the credit finance not only increases the amount of loans raised by companies, but also allows some firms facing financial constraints to access to capital markets unattainable for them up to date. The outcome of such a process is the financial accelerator (Bernanke, Gertler and Gilchrist, 1996), that is to say, the amplification of initial shocks brought about by changes in credit market conditions.

On the contrary, a contractionary shock to economy reduces firms' ability to borrow. The most constrained companies are forced to cut back their investment which, for this reason, reduce their future revenues and their net worth. Hence, these firms become more and more constrained, propagating and amplifying the contractionary shock (Fuerst, 1995; Kiyotaki and Moore, 1995; Bacchetta and Caminal, 1996). ${ }^{140}$ Moreover, corporate financial structure could affect macroeconomic performance by creating debt overhang (Lamont, 1995). This situation occurs when firms reject

\footnotetext{
${ }^{139}$ Gertler (1988) gives an comprehensive survey on the macroeconomic implications of asymmetric information.

${ }^{140}$ This is the basic mechanism. Some authors have shown that it is not an immediate reaction, but there is a lag of several quarters so that business and households adjust their financial assets and liabilities.
} 
investment projects with positive NPV because their benefits do not go to new investors. If economy is not booming, debt overhang will bind, as the returns are too low and the economy becomes more sensitive to recession.

Almost unanimously the conclusion raised in the literature is the prominent role played by constrained firms in financial and economic cycles. Furthermore, this kind of companies account for a disproportionate share of the effects following a shift to tight money (Gertler and Gilchrist, 1994). That is why a good approximation to the consequences of monetary policy relies on the identification of the most constrained firms. As a matter of fact, there are numerous papers which divide the firms into constrained and unconstrained depending on several criteria such as size (Carpenter, Fazzari and Petersen, 1994; Rippington and Taffler, 1995; Bernanke, Gertler and Gilchrist, 1996), dividend payout (Fazzari, Hubbard and Petersen, 1988; Alonso, 1994; Bond and Meghir, 1994), bank relationship (Hoshi, Kashyap and Scharfstein, 1990a, b and 1991; Schaller, 1993), capital intensity (Anderson, 1990), ownership dispersion (Devereux and Schiantarelli, 1990), etc.

\section{METHODOLOGY AND DATA.}

As we have said, the aim of the empirical work of this paper is to explore the way in which monetary policy decisions influence on real investment and aggregate output. Whereas in capital markets where firms usually get funds there is not a perfect stream of information among all individuals, it is evident that an adequate explanation of the transmission mechanism has to be close to the credit channel. Keeping this in mind, the most clear-sighted approach is analyzing the correlations among output, bank debt and the stance of monetary policy (King, 1986). Nonetheless, this method is troubled by the problem of identifying shifts in loan demand from shifts in loan supply (Oliner and Rudebusch, 1996), so a comparison of different sorts of credits should be established.

Furthermore, as Kashyap, Stein and Wilcox (1993) argue, if a monetary shock operated through the interest rate channel, this fact should alter all kinds of finance while, if it operated through the credit channel, the only source affected would be the bank debt. We follow this idea and build a relative measure of a firm's bank debt in which all the liabilities are included in a way we think is informative about the utilization of bank finance by companies. ${ }^{141}$

Besides the composition of external finance, another essential point is the choice of one or more indicators of the stance of monetary policy. Unfortunately, as some authors have indicated, measuring the stance of monetary policy is not a straightforward task. Although different versions may be used, there is an almost general agreement about some indicators and, in fact, many of the qualitative conclusions reached in any case are quite similar. Perhaps, the most commonly used one in US is the federal funds rate (Bernanke and Blinder, 1992; Kashyap, Stein and Wilcox, 1993; Christiano, Eichenbaum and Evans, 1996; Oliner and Rudebusch, 1996) although it is not the only one. For instance, sometimes standard macroeconomic aggregates like GDP, employment, retail sales or corporate profits have been used to identify shifts to tighter policies (Christiano, Eichenbaum and Evans, 1996) or even the reading of the minutes of Federal Open Market Committee meetings (Romer and Romer, 1990).

Nevertheless, the federal funds rate is a measure of monetary policy extremely informative about future movements of real macroeconomic variables and its movements are genuine policy changes, not simple endogenous responses to changes in the economy (Bernanke and Blinder, 1992). Moreover, the funds rate is a good reduced predictor of major macroeconomic variables and, at the same time, it responds to the Fed's perception of the state of the economy. This claim is consistent with the well-known fact that nominal interest rates are good predictors of real variables and it only adds the recognition that the federal funds rate -or its equivalent for other countries- is particularly informative.

That is the reason why we have chosen this instrument as the main indicator of the stance of monetary policy. Specifically, we have to bear in mind that nominal interest rates affect a firm's cash

\footnotetext{
${ }^{141}$ The choice of a firm's bank finance measurement is not a trivial question and could help to explain some opposite results reached in other works (see Kashyap, Stein and Wilcox, 1993 and 1996 vs. Oliner and Rudebusch, 1996).
} 
flow and short-term interest rates play a special role in the credit transmission channel because interest payments on short-term debt have greater impact on a firm's cash flow than interest payments on longterm debt (Mishkin, 1996).

As regards our sample, it initially included data from 15 countries in the OECD: Austria, Belgium, Canada, Denmark, Finland, France, Germany, Italy, Japan, the Netherlands, Norway, Spain, Sweden, UK and USA. However, Denmark and Germany made no distinction between bank and nonbank liabilities, so they did not give the information we needed and they were not considered. As for the remaining countries -with the former exception of US- it is not easy to get the equivalent rate to the federal funds rate, and therefore we have tried to make use of an interest rate which can be interpreted as the Central Bank perception of the current and future situation of the economy. When available it was the treasury bill rate and, occasionally, the call money rate or other typical short-term interest rate. In any case, the data were collected from the OECD publications "Main Economic Indicators" and, in spite of covering from 1964 to 1994, a certain country-heterogeneity regarding time can be observed.

Going on with the description of the sample, table 1 shows the main features considered: kind of interest rate used, timing and an indicator of the relative importance of the companies contained in the sample relative to the GDP. France was initially included but it presented data for just five years, so it has not been taken into consideration. It is patently obvious the varying importance of the companies in the sample over the whole economic complex of the country, and the countries whose sample is more representative seem to be those out of the continental Europe.

In addition to these general features of the sample, another very important source of data was the "Non-financial enterprises financial statements" edited by the OECD. These statements regroup related tables on private non-financial corporations which may include either the entire sector or a sample depending on the country. Data were selected regarding balance sheet structure and the statement of income and change in net worth. These are not firm-level but aggregate data, which is one of the most prominent limitations of the present paper. However it allows us to do international comparisons even though there can be differences in the methods used for calculations and valuations among all countries.

\begin{tabular}{|c|c|c|c|c|c|}
\hline Austria & Official discount rate/Treasury bill & $1973-1994$ & $31.35 \%$ & $41.67 \%$ & $40.94 \%$ \\
\hline Belgium & 3-month Treasury certificates & $1978-1994$ & $19.00 \%$ & $20.16 \%$ & $141.14 \%$ \\
\hline Canada & Call money rate/90-day deposits receipt & $1968-1994$ & $51.57 \%$ & $39.70 \%$ & $164.35 \%$ \\
\hline Finland & Call money rate/3-month Helibor & $1974-1993$ & $28.72 \%$ & $29.63 \%$ & $72.48 \%$ \\
\hline Italy & 6-month Treasury bill & $1982-1994$ & $19.23 \%$ & $25.16 \%$ & $53.51 \%$ \\
\hline Japan & 3-month Gensaki & $1974-1994$ & $38.22 \%$ & $47.63 \%$ & $245.18 \%$ \\
\hline The Netherlands & 3-month loans to local authorities & $1983-1993$ & $15.39 \%$ & $24.35 \%$ & $105.89 \%$ \\
\hline Norway & Call money rate/3-month Nibor & $1970-1993$ & $5.31 \%$ & n.a. & $48.61 \%$ \\
\hline Spain & Call money rate/3-month interbank loans & $1983-1994$ & $29.53 \%$ & $42.25 \%$ & $47.58 \%$ \\
\hline Sweden & 3-month Treasury discount notes & $1980-1993$ & $14.71 \%$ & $9.09 \%$ & $125.42 \%$ \\
\hline United Kingdom & 91-day Treasury bill & $1982-1994$ & $37.08 \%$ & n.a. & $191.67 \%$ \\
\hline United States & Federal funds rate & $1964-1994$ & $32.44 \%$ & $33.88 \%$ & $155.08 \%$ \\
\hline
\end{tabular}

Table 1: Main characteristics of the sample. The fourth and fifth columns express the average short-term and long-term bank leverage respectively, while the last one shows the total asset of the companies included in the sample as a mean percentage of the GDP.

Obviously, it would have been preferable to utilize firm-level data or, at least, semi-aggregate data (Rondi et al., 1993; Oliner and Rudebusch, 1996) so as to compare the reaction of different sorts of companies after a monetary policy shift given the special severity of information problems for some of them, which could increase specially cost and scarcity of funds. Another caveat about the sample is its extremely low periodicity. Reactions after monetary policy shifts are predominantly a short-term issue and thus quarterly or even monthly data would have been more useful than end-of-the-year balance sheets. Unfortunately we are not aware of a data base for several OECD countries with less than annual periodicity. This fact is not trivial because bank credit can be affected by previous stances of monetary policy, so some lagged variables should be taken into account. These lags are hardly more 
than eight quarters and therefore our model will not consider more than two-year lags in spite of the loss of information and predictive capacity it implies.

Once we compiled the balance sheet data, two indicators of bank financial leverage were calculated. It should be not forgotten that a possible response to tighter monetary policy consists in reducing bank credits and, in turn, lowering investment and output. In such a situation, if credit channel did not operate, firms would choose to substitute their bank finance for some sort of liabilities such as commercial paper, bonds, etc. As it was previously stated, a simple correlation among interest rates and bank finance poses the problem of the identification and does not deal explicitly with the issue of the endogeneity. Trying to solve this difficulty we have defined two leverage ratios: the shortterm bank finance ratio and the long-term bank finance ratio whose average values for each country can be found in table $1^{142}$.

In both of them the numerator just includes bank credits and the denominator is the sum of all liabilities (naturally, for the short-term ratio, only short-term liabilities are included). In so doing, we have a measure of the firm's bank debt relative to other sources of debt. Although the credit view underlying this ratio has not been always empirically successful, it reflects a money versus credit debate where credit issues are gradually prevailing. While the money view rests on the idea that the main transmission instrument is bank liabilities, the credit view emphasizes the asset side of bank balance sheets because there is a large fraction of borrowers who cannot find substitutes of bank credit, so any constraint on this kind of finance has important effects on them. Given the close relationship between bank assets and firms' credits, this is the reason why we focus on the liability side of non financial company balance sheet.

A last indication must be given about the introduction of GDP. It could happen that bank credit was affected by some cyclical factors others than monetary policy. In order to exert control over these factors, two separate tests will be made: one of them considers the influence of GDP and the other eliminates it. GDP data at current prices were collected from the OECD publication "Main economic indicators" and the UNO publication "National Accounts Statistics"

Regarding the econometric methodology, and provided that we would like to explore the possible results of a credit channel, we should do causality tests to see if movements in the monetary policy variables help to forecast movements in firms' financial choices. One of the most accurate techniques is therefore the vector autoregressions (VAR), which allows us to examine the correlation between the interest rate indicator and the finance ratios, doing at the same time the Granger causality test. ${ }^{143} \mathrm{~A}$ VAR is a system of ordinary least squares regressions, in which each variable is regressed on lagged values of itself and other variables. In this framework the variables used must be in stationary form, so they have been differenced in order to guarantee their stationary character.

When VARs are applied it is usual to present the impulse response to shifts in some of the endogenous variables. However, due to the peculiar timing of our model we think it is senseless to calculate the influence after four or more periods of a variable when the order of the autoregresive model is just one. This is clearly another limitation of this paper even though its purpose is not to quantify the response, but only to outline an international framework for the analysis of the monetary policy transmission channels.

\section{RESULTS.}

We have argued it is not easy to distinguish between the effects of the balance sheet channel and the effects of the bank lending channel as two compatible elements of the credit channel of monetary transmission. A further explanation would require an additional analysis of the causes of the shift in the credit lending which we cannot make. So, the evidence we have found supports, at least partially, the credit channel but it does not dispel the doubt about the relative influence of the two "subchannels".

\footnotetext{
${ }^{142}$ There are two exceptions (United Kingdom and Norway) because they do not present their short and longterm bank credits separately.

${ }^{143}$ The robustness of the structural inferences made from unrestricted VAR is risky and depends heavily on the isolation of a measure of Central Bank policy (for a discussion about the problems to measure structural effects of a policy change, see Bernanke and Blinder, 1992).
} 
In spite of it, our research reveals that the balance sheet channel does work. There are various indicators of the firm's collateral and among all of them we have chosen the "coverage ratio" defined as the ratio of interest payments to gross income finance (retained income before depreciation and provisions) ${ }^{144}$. Moreover, some studies have demonstrated the advantages of using this proportion to signal the firms' financial condition (Whited, 1992; Nickell and Nicolitsas, 1994). In our opinion, the retained income is very informative about the firm's ability to generate funds so the above ratio should be highly correlated with the other indicators of the firms' financial health.

Figures 1-11 plot the coverage ratio along with the interest rate for all the countries in the sample. There seems to be a relation between the two variables, although this relation is closer in some countries than in others. Notwithstanding it can be interpreted as a first approximation to the existence of a balance sheet channel. Suppose the causality runs from the interest rate to the coverage ratio (which is the most plausible). The conclusion we can reach is that tighter monetary policy indeed increases interest rate and weakens the firms' financial health by increasing interest payments and reducing profits

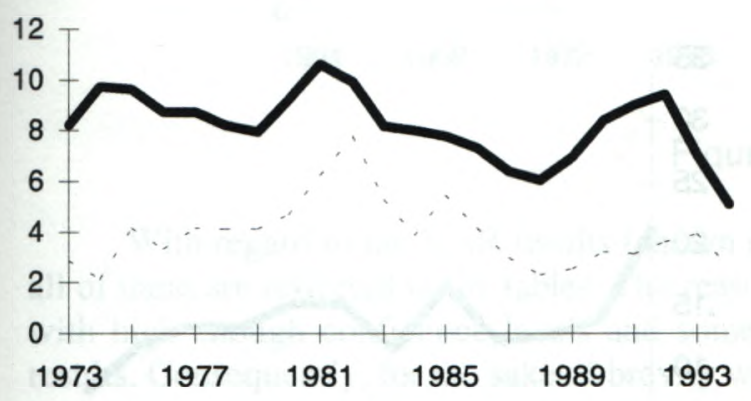

Figure 1: Austria

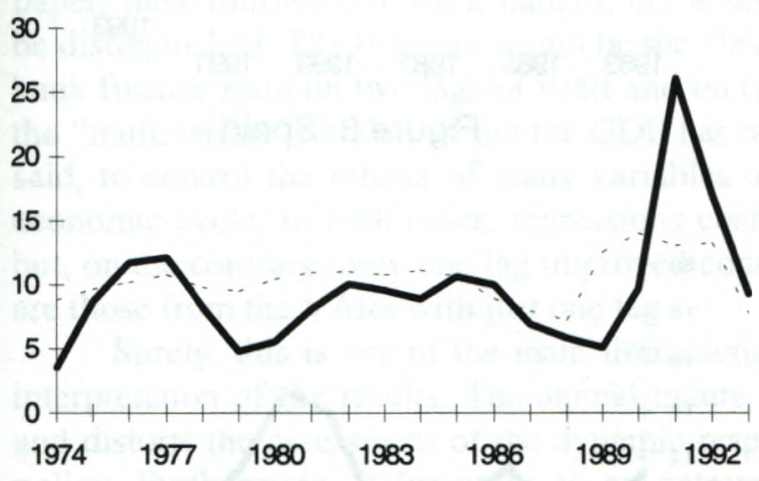

Figure 3: Finland

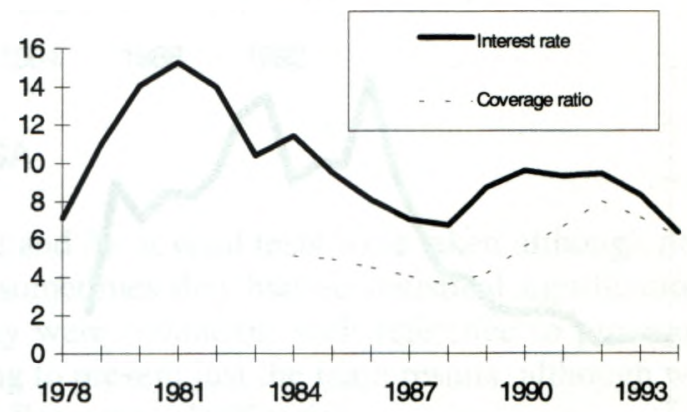

Figure 2: Belgium

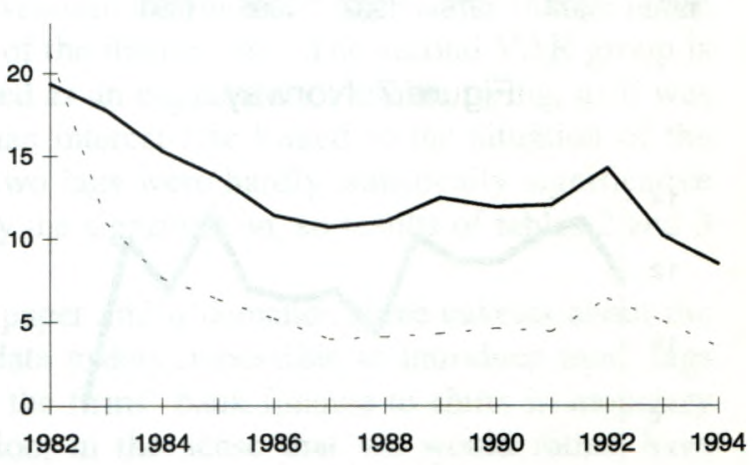

Figure 4: Italy

\footnotetext{
${ }^{144}$ The coverage ratio is actually defined as the inverse of the ratio we have defined. Although it is not the first time this definition has been provided (Bernanke and Gertler, 1995), we have done so because we think it is helpful and more intuitive to understand the relationship with the instruments of the monetary policy and its graphic representation is easier to see.
} 


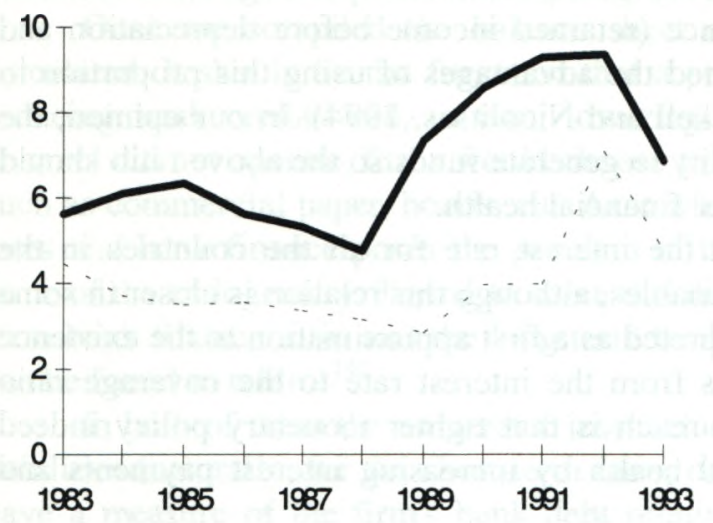

Figure 5: Japan

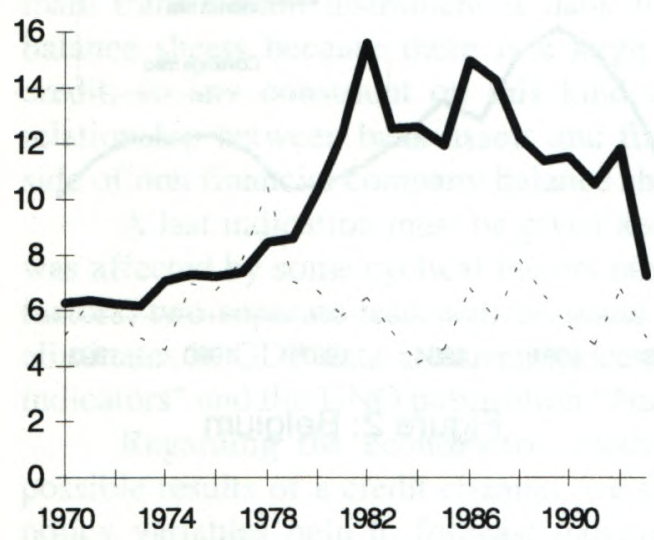

Figure 7: Norway

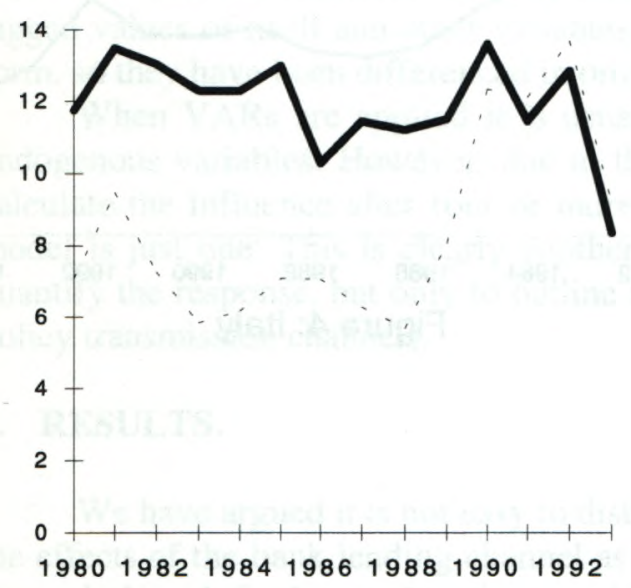

Figure 9: Sweden

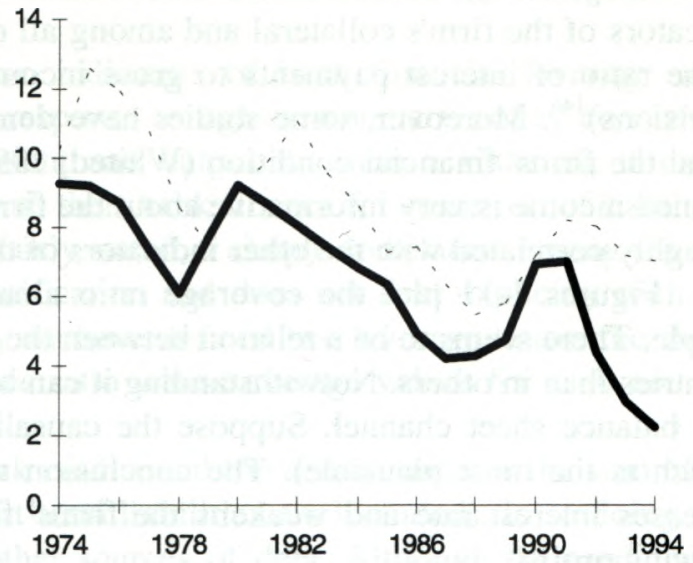

Figure 6: The Netherlands

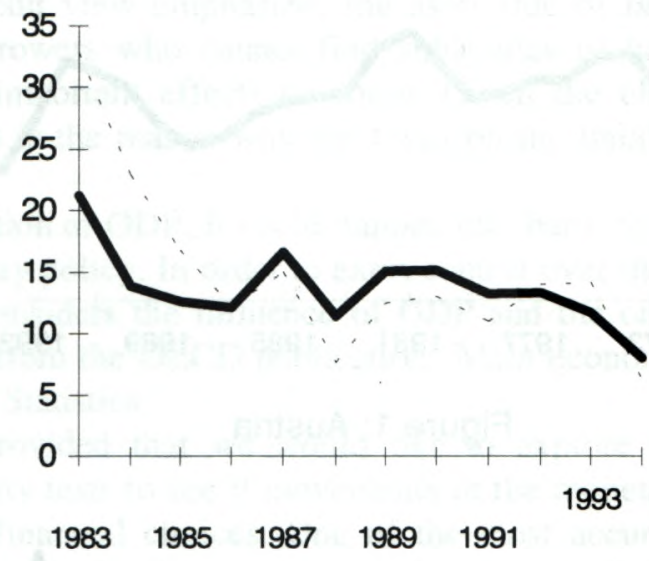

Figure 8: Spain

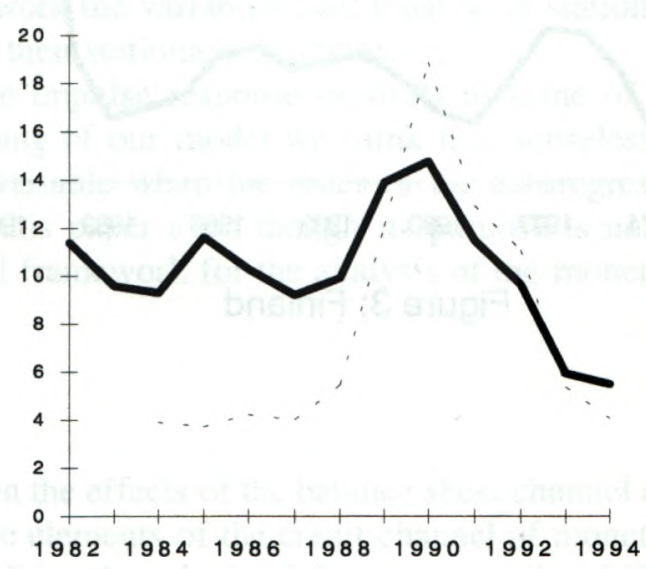

Figure 10: United Kingdom 


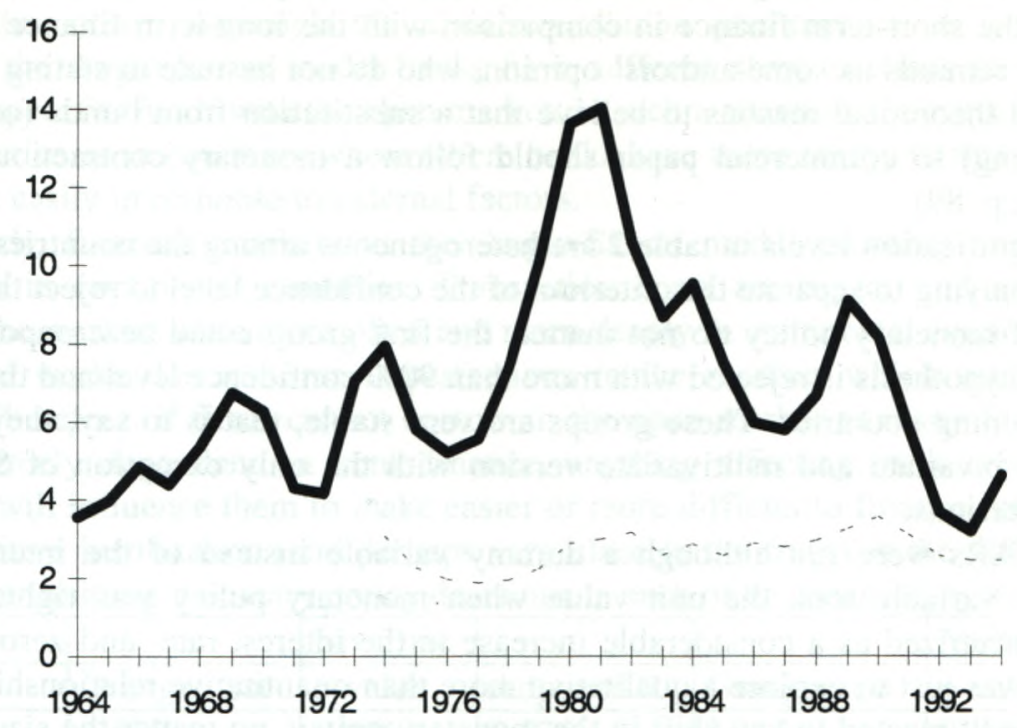

Figure 11: USA

With regard to the VAR results (shown in tables 2 and 3), several tests were taken although not all of them are reflected in the tables. The reason is that sometimes they had no statistical signification with high enough confidence levels and sometimes they were redundant with reference to previous results. Consequently, for the sake of brevity we are going to present just the main results, although we will refer to others in making some comparisons or providing some clarification.

Although this is not a new research method about monetary policy transmission and some papers have followed the same pattern, in the set of VARs we have done, two groups of estimates can be distinguished. The first one would be the "bivariate" version, in which we regress the change in the bank finance ratio on two lags of itself and on two lags of the interest rate. The second VAR group is the "multivariate" version where the GDP has been added as an explanatory variable trying, as it was said, to control the effects of many variables others than interest rate linked to the situation of the economic cycle. In both cases, regressions containing two lags were hardly statistically significative but, on the contrary, only one lag improved considerably the signification, so results of tables 2 and 3 are those from the VARs with just one lag.

Surely, this is one of the main limitations of the paper and it demands some caveats about the interpretation of the results. The annual nature of the data makes impossible to introduce more lags and distorts the assessment of the dynamic response of the firms' bank finance to shifts in monetary policy. Furthermore, it forces us to an extreme position, in the sense that we would rather have introduced lags of just a few months in the VAR -trying to reflect short-term responses-, but not of a whole year.

However two remarks are pertinent to the matter. On one hand, we think results remain valid, that is to say, the possible influence -or lack of it- of previous stances of monetary policy is not so contingent on the timing as to modify completely the scheme of results. The aim of the paper is to prove the fact that previous monetary policy does matter -or does not- in later firms' financial choices without dependence on the number of months it takes to affect. On the other hand, this paper comprises a first attempt to international comparison for the purpose of testing if the bank credit channel works in all the countries. Given that all our data are annual, the comparison can be drawn, although naturally a more detailed analysis and assessment of the duration of monetary policy decisions requires a different sort of data.

Perhaps the more outstanding result is the Granger causality test in order to examine the influence of previous stances of monetary policy on firms' financial choices. As illustrated in table 2, both in the bivariate and the multivariate model, previous stances of monetary policy do affect the bank finance of companies in an important group of countries. It is convenient to note that these results refer just to the short-term bank finance ratio. Those corresponding to the long-term bank 
finance ratio (table 3) were not often significant, which could be interpreted as a confirmation of the special role played by the short-term finance in comparison with the long-term finance in the credit transmission channel. It reminds us some authors' opinion, who do not hesitate in stating that they are "not aware of any good theoretical reasons to believe that a substitution from bonds (or other longterm sources of financing) to commercial paper should follow a monetary contraction" (Kashyap, Stein and Wilcox, 1993, p. 89)

Although the signification levels in table 2 are heterogeneous among the countries, two groups of countries emerge. Applying to separate the criterium of the confidence level to reject the hypothesis that previous stances of monetary policy do not matter, the first group could be composed by those countries for which the hypothesis is rejected with more than $90 \%$ confidence level and the second one would include the remaining countries. These groups are very stable, that is to say, they contain the same countries both in bivariate and multivariate version with the only exception of Spain, whose values change in both versions.

Some similar VARs were run although a dummy variable instead of the interest rate was preferred. This dummy variable took the unit value when monetary policy was tighter enough -a tighter policy was characterized as a considerable increase in the interest rate- and zero-value in the other case. The reason was just to explore a qualitative more than quantitative relationship or, what is the same, if the bank credit reacted to any shift in the monetary policy, no matter the size of the shift. The results seemed to validate the previous set of VARs, showing the same relation between monetary policy and bank finance availability although they were not so strong and consistent.

The composition of the two groups of countries reveals an important feature of them as the rule for the allocation seems to be the kind of financial system. There is no doubt that all the countries studied in this paper are homogeneous in the sense that they are developed countries, with a similar productive structure among sectors, with strong international relations, etc. However, the main differences can be found in their financial system (Allen and Gale, 1994). Two kinds of financial systems are usually distinguished: the market-oriented model and the bank-oriented model. Among their well known peculiarities, we would just like to stress that they could be resumed in the quite distinct weight of financial intermediaries in the investment process. Whereas in the market-based model lenders get in touch directly with borrowers without the help of any financial institution, in the continental or bank-based financial system banks receive a large fraction of savings and direct it to profitable investment opportunities. The paradigms of the first model are USA and UK, while Germany and Japan are examples of the second one.

\begin{tabular}{|l|l|l|l|l|l|l|}
\hline & & Bivariate & & & Multivariate & \\
\hline Country & Granger test & p-value & Adjusted $\mathrm{R}^{2}$ & Granger test & p-value & Adjusted $\mathrm{R}^{2}$ \\
\hline Austria & 5.146 & 0.037 & 0.777 & 4.820 & 0.024 & 0.585 \\
\hline Belgium & 4.761 & 0.054 & 0.763 & 3.449 & 0.073 & 0.793 \\
\hline Canada & 2.649 & 0.118 & 0.476 & 1.354 & 0.258 & 0.530 \\
\hline Finland & 13.966 & 0.001 & 0.927 & 11.961 & 0.002 & 0.942 \\
\hline Italy & 5.787 & 0.043 & 0.588 & 8.788 & 0.021 & 0.574 \\
\hline Japan & 8.333 & 0.011 & 0.617 & 4.885 & 0.025 & 0.626 \\
\hline The Netherlands & 4.933 & 0.068 & 0.526 & 4.908 & 0.078 & 0.507 \\
\hline Norway & 9.742 & 0.006 & 0.907 & 5.241 & 0.017 & 0.903 \\
\hline Spain & 20.800 & 0.003 & 0.988 & 3.890 & 0.106 & 0.983 \\
\hline Sweden & 9.216 & 0.014 & 0.533 & 4.550 & 0.065 & 0.510 \\
\hline United Kingdom & 0.049 & 0.829 & 0.684 & 0.522 & 0.493 & 0.789 \\
\hline United States & 1.500 & 0.232 & 0.435 & 2.527 & 0.124 & 0.420 \\
\hline
\end{tabular}

Table 2: Causality tests between short-term bank finance and indicators of the stance of monetary policy. The p-value deals with the test that coefficients of the lagged variables representing the stance of monetary policy are zero.

As illustrated in the results we have reached, countries with a market-oriented system (USA, UK and Canada) are those in which previous stances of monetary policy have less impact on bank 
credit. This is not a casual outcome but there are theoretical reasons to justify it (Bernanke and Gertler, 1995; Mishkin, 1996). Although the disintermediation phenomenon is a common trend in all countries, in the Anglo-Saxon model banks have suffered sharp declines in deposits and have less means to compete for funds with the open market. In such a situation, the bank credit channel logically is not so effective as in countries where where banks have more ability to raise funds and bank credit may fluctuate easily in response to external factors.

In other words, financial markets in the Anglo-Saxon model probably are more developed and efficient than in continental countries. Transaction costs are bigger and asymmetric information problems in the markets arise more often and more deeply in continental countries. As it was said, the credit channel works due to some imperfections in the markets which make firms face financial constraints. Therefore, if firms cannot borrow in the open market as many funds as they would like and are extremely dependent on bank finance, anything affecting bank credit conditions (i.e. the interest rate) will influence them to make easier or more difficult to finance their investments. This is the most intuitive justification (and perhaps very close to the truth) of the different scope that banks can have in transmitting monetary policy decisions in each of the financial systems.

\begin{tabular}{|l|l|l|l|l|l|l|}
\hline & & Bivariate & & & Multivariate & \\
\hline Country & Granger test & $\mathrm{p}$-value & Adjusted $\mathrm{R}^{2}$ & Granger test & p-value & Adjusted $\mathrm{R}^{2}$ \\
\hline Austria & 3.579 & 0.076 & 0.526 & 2.112 & 0.167 & 0.210 \\
\hline Belgium & 1.297 & 0.277 & 0.661 & 0.494 & 0.497 & 0.274 \\
\hline Canada & 1.286 & 0.269 & 0.292 & 0.105 & 0.748 & 0.287 \\
\hline Finland & 1.737 & 0.207 & 0.776 & 1.703 & 0.211 & 0.529 \\
\hline Italy & 3.745 & 0.094 & 0.308 & 3.065 & 0.131 & 0.220 \\
\hline Japan & 2.120 & 0.165 & 0.706 & 2.059 & 0.171 & 0.242 \\
\hline The Netherlands & 0.859 & 0.390 & 0.645 & 2.414 & 0.181 & 0.581 \\
\hline Spain & 1.648 & 0.240 & 0.931 & 2.226 & 0.203 & 0.461 \\
\hline Sweden & 13.426 & 0.005 & 0.554 & 3.767 & 0.088 & 0.303 \\
\hline United States & 0.877 & 0.357 & 0.470 & 0.602 & 0.445 & 0.440 \\
\hline
\end{tabular}

Table 3: Causality tests between long-term bank finance and indicators of the stance of monetary policy.

\section{CONCLUSIONS.}

The relationship between monetary policy and economy is not a new issue in economic research. Notwithstanding, although several theories have tried to explain the way through which monetary policy affects the aggregate investment and output, there are some aspects of the question left without an appropriate response. Macroeconomic approaches seem not to be enough to explain the monetary policy transmission and some new perceptions are necessary.

Perhaps the most promising answers come from the knowledge of the imperfections in financial markets and the changes that such imperfections provoke in corporate finance. In this framework, the credit channel emphasizes the role of banks to overcome the asymmetric information problems and presents these institutions as instruments able to influence on the economic aggregate activity through the monetary policy. In short, the credit channel considers that a tightening of the monetary policy diminishes firms' liabilities (by decreasing the collateral and making more difficult to get bank finance), what leads to a reduction in investment.

In this paper we make an international comparison of the incidence of the credit channel among twelve OECD countries. To achieve this aim we choose a typical short-term interest rate as indicator of the stance of monetary policy in every country and we interpret every increase as synonymous to a tightening of the monetary policy. Our first and most prominent finding is that monetary policy does have a way to influence in the economy through the bank credit availability. As a matter of fact we reach the conclusion that previous stances of the monetary policy are correlated with future firms' bank financing. This influence is particularly evident in the short-term whereas more than one year lagged variables have no longer had statistical signification. 
Another outstanding result is the dependence between the efficacy of the credit channel of transmission and the kind of financial system. Those countries with a market based financial system seem to show more alternatives to bank finance and hence, financial institutions become less effective in transmitting monetary policy by altering the credit availability. Given that there is a generalized trend in almost all the countries to the disintermediation, it could be thought that the bank lending channel (one of the components of the credit channel) is going to lose importance in the next years.

However some caveats are necessary. First of all, the data structure is not the optimal to make any inference. They are annual data, too long periodicity for our purpose. A quarterly pattern would have been more useful, allowing us to test more exactly the timing of the firms' response to changes in monetary policy. At the same time, caution is necessary because we have used aggregate data. Obviously, firm-level data would have been desirable, and this is an issue for further research in order to analyze if companies with different size, bank relationship, age, etc. display heterogeneous responses to monetary policy variations. Of course, the field of future research is enormous. With this paper we just want to do an initial approximation in an international framework. Future studies have to validate or refute this emerging evidence.

\section{REFERENCES.}

ALLEN, F. and GALE, D. (1994): "A Welfare Comparison of the German and U.S. Financial Systems". CEPR-Fundación BBV Conference on Industrial Organization and Finance. April. San Sebastián (Spain).

ALONSO, C. (1994): "Estimating Dynamic Investment Models with Financial Constraints". Centro de Estudios Monetarios y Financieros. Working paper n. 9418.

ANDERSON, G. (1990): “An Empirical Note on the Independence of Technology and Financial Structure". Canadian Journal of Economics. vol. 23, n. 3. pp. 693-699.

BACCHETTA, P. and CAMINAL, R. (1996): "Do Capital Market Imperfections Exacerbate Output Fluctuations?" Mimeo.

BERNANKE, B.S. and BLINDER, A. S. (1992): "The Federal Funds Rate and the Channels of Monetary Transmission". American Economic Review. vol. 82, n. 4, pp. 901-921.

BERNANKE,B. and GERTLER, M. (1995): "Inside the Black Box: The Credit Channel of Monetary Policy Transmission". Journal of Economic Perspectives. vol. 9, n. 4. pp. 27-48.

BERNANKE, B., GERTLER, M. and GILCHRIST, S. (1996): "The Financial Accelerator and the Flight to Quality". The Review of Economics and Statistics. vol. 78, n. 1, pp. 1-14.

BLINDER, A. S. and MACCINI, L. J. (1991): "Taking Stock: A Critical Assessment of Recent Research on Inventories". Journal of Economic Perspectives. vol. 5, n. 1, pp. 73-96.

BOND, S. and MEGHIR, C. (1994): "Dynamic Investment Models and the Firm's Financial Policy". Review of Economic Studies. vol. 61, n. 2, pp. 197-222.

BROER, D. P. and LEEUWEN, G. van (1994): "Investment Behaviour of Dutch Industrial Firms. A Panel Data Study". European Economic Review. vol. 38, n. 8, pp. 1555-1580.

CALEM, P. S. and RIZZO, J. A. (1995): "Financing Constraints and Investment: New Evidence from Hospital Industry Data”. Journal of Money, Credit and Banking. vol. 27, n. 4. pp. $1002-$ 1014.

CALOMIRIS, C. W. and HUBBARD, R. G. (1989): "Price Flexibility, Credit Availability, and Economic Fluctuations: Evidence from the United States, 1894-1909". Quarterly Journal of Economics. vol. 104, n. 3, pp. 429-452.

CALOMIRIS, C. W. and HUBBARD, R. G. (1990): "Firm Heterogeneity, Internal Finance, and 'Credit Rationing'“. The Economic Journal, vol. 100, n. 399, pp. 90-104.

CALOMIRIS, C. W. and HUBBARD, R. G. (1995): "Internal Finance and Investment: Evidence from the Undistributed Profits Tax of 1936-37”. Journal of Business. vol. 68, n. 4, pp. 443-482.

CALOMIRIS, C. W., ORPHANIDES, A. and SHARPE, S.A. (1994): "Leverage as a State Variable for Employment, Inventory Accumulation, and Fixed Investment". NBER Working Paper n. 4800.

CARPENTER, R. E., FAZZARI, S. M. and PETERSEN, B. C. (1994): "Inventory Investment, Internal Finance Fluctuations, and the Business Cycle". Brooking Papers on Economic Activity. vol. 2, pp. 75-138. 
CHEVAlliER-FARAT, T. (1992): "Pourquoi des banques?" Revue d'Économie Politique. n. 102, vol. 5. pp. 633-685.

CHIRINKO, R. (1993): "Business Fixed Investment Spending: A Critical Survey of Modeling Strategies, Empirical Results, and Policy Implications". Journal of Economic Literature. vol. 31, pp. 1875-1911.

CHRISTIANO, L.J.; EICHENBAUM, M. S. and EVANS, C. (1996): "The Effects of Monetary Policy Shocks: Evidence from the Flow of Funds". The Review of Economics and Statistics. vol. 78, n. 1, pp. 16-34

DEVEREUX, M. and SCHIANTARELLI, F. (1990): "Investment, Financial Factors, and Cash Flow: Evidence from U.K. Panel Data". R. G. Hubbard (Ed.): Asymmetric information, corporate finance and investment. The University of Chicago Press. Chicago. pp. 279-306.

FAZZARI, S. M., HUBBARD, R. G. and PETERSEN, B. C. (1988): "Financing Constraints and Corporate Investment". Brooking Papers on Economic Activity, vol. 1, pp. 141-195.

FAZZARI, S. M. and PETERSEN, B. C. (1993): "Working Capital and Fixed Investment: New Evidence on Financing Constraints". RAND Journal of Economics. vol. 24, n.3, pp. 328-342

FUERST, T. S. (1995): "Monetary and Financial Interactions in the Business Cycle". Journal of Money, Credit and Banking. vol. 27, n. 4. pp. 1321-1338.

GALEOTTI, M., SCHIANTARELLI, F. and JARAMILLO, F. (1994): "Investment Decisions and the Role of Debt, Liquid Assets and Cash Flow: Evidence from Italian Panel Data". Applied Financial Economics. vol. 4, n. 2, pp. 121-132.

GERTLER, M. (1988): "Financial Structure and Aggregate Economic Activity: An Overview". Journal of Money, Credit, and Banking. vol. 20, n.3, pp. 559-588.

GERTLER, M. and GILCHRIST, S. (1994): "Monetary Policy, Business Cycles, and the Behavior of Small Manufacturing Firms". Quarterly Journal of Economics. vol. 109. n. 2, pp. 309-340.

GERTLER, M., HUBBARD, R. G. and KASHYAP, A. (1991): "Interest Rate Spreads, Credit Constraints, and Investment Fluctuations: An Empirical Investigation”. R. G. Hubbard (Ed.): Financial markets and financial crises. The University of Chicago Press. Chicago, pp. 11-31.

GILCHRIST, S. and HIMMELBERG, C. P. (1995): "Evidence on the Role of Cash Flow for Investment." Journal of Monetary Economics. vol. 36, pp. 541-572.

GREENWALD, B., STIGLITZ, J. E. and WEISS, A. (1984): "Informational Imperfections in the Capital Market and Macroeconomic Fluctuations”. American Economic Review. vol. 74, n.2, pp. 194-199.

HOSHI, T., KASHYAP, A. and SCHARFSTEIN, D. (1990a): "The Role of Banks in Reducing the Costs of Financial Distress in Japan”. Journal of Financial Economics. vol. 27, n.1, pp. 67-88.

HOSHI, T., KASHYAP, A. and SCHARFSTEIN, D. (1990b): "Bank Monitoring and Investment: Evidence from the Changing Structure of Japanese Corporate Banking Relationships". R. G. Hubbard (Ed.): Asymmetric information, corporate finance and investment. The University of Chicago Press. Chicago, pp. 105-126.

HOSHI, T., KASHYAP, A. and SCHARFSTEIN, D. (1991): "Corporate Structure, Liquidity and Investment: Evidence from Japanese Industrial Groups". Quarterly Journal of Economics. vol. 106, n.1, pp. 33-60.

HUBBARD, R. G. (1994): “Is There a Credit Channel for Monetary Policy?” NBER Working Paper. n. 4977.

HUBBARD, R. G. and KASHYAP, A. K. (1992): "Internal Net Worth and the Investment Process: An Application to U.S. Agriculture”. Journal of Political Economy. vol. 100, n. 3, pp. 506-534.

HUBBARD, R. G., KASHYAP, A. K. and WHITED, T. M. (1995): "Internal Finance and Firm Investment". Journal of Money, Credit and Banking. vol. 27, n. 3. pp. 683-701.

JORGENSON, D. W. (1963): "Capital Theory and Investment Behavior". American Economic Review. vol. 53, n.1, pp. 247-259.

JORGENSON, D. W (1967): “The Theory of Investment Behavior". Determinants of investment behavior. Universities-NBER Comittee for Economic Research. New York. pp. 129-155.

KASHYAP, A. K., LAMONT, O. A. and STEIN, J. C. (1994): "Credit Conditions and the Cyclical Behavior of Inventories". Quarterly Journal of Economics. vol. 109, n. 3, pp. 565-592. 
KASHYAP, A. K., STEIN, J. C. and WILCOX, D. W. (1993): "Monetary Policy and Credit Conditions: Evidence from the Composition of External Finance". American Economic Review. vol. 83, n. 1, pp. 78-98.

KASHYAP, A.K., STEIN, J.C. and WILCOX, D.W. (1996): "Monetary Policy and Credit Conditions: Evidence from the Composition of External Finance: Reply". American Economic Review. vol 86, no.1, pag. 310-314.

KING, S.R. (1986): "Monetary Transmission: Through Bank Loans or Bank Liabilities". Journal of Money, Credit, and Banking. vol. 18, pp. 290-303.

KIYOTAKI, N. and MOORE, J. (1995): Credit Cycles. Mimeo

LAMONT, O. (1995): "Corporate-Debt Overhang and Macroeconomic Expectations". American Economic Review. vol. 85, n. 5. pp. 1106-1117.

MELTZER, A. H. (1995): "Monetary, Credit (and Other) Transmission Processes: A Monetarist Perspective". Journal of Economic Perspectives. vol. 9, pp. 49-72.

MISHKIN, F. S. (1995): "Symposium on the Monetary Transmission Mechanism". Journal of Economic Perspectives. vol. 9, n. 4. pp. 3-10.

MISHKIN, F. S. (1996): "The Channels of Monetary Transmission: Lessons for Monetary Policy". NBER Working Paper n. 5464.

NICKELL, S. and NICOLITSAS, D. (1994): “How Does Financial Pressure Affect Firms?". Mimeo. 